\title{
Pengembangan Video Sex Education Untuk Menstimulasi Kemampuan Sosial Emosional Anak Usia Dini
}

\author{
Norma Diana Fitri \\ normadiana79@gmail.com \\ STKIP Bina Insan Mandiri Surabaya
}

\begin{abstract}
Abstrak
Penelitian ini bertujuan untuk mengembangkan video sex education untuk menstimulasi kemampuan sosial dan emosional anak usia dini. Model pengembangan yang digunakan dalam penelitian ini adalah model (Gall, Gall, \& Borg, 2011) yang terdiri sepuluh langkah. (1) Asses Needs To Identity Goal, (2) Conduct Instructional Analysis, (3) Analyze Learners And Context, (4) Write Performance Objectives, (5) Develop Assessment Instrument, (6) Develop Instructional Strategy, (7) Develop And Select Instructional Materials , (8) Design And Conduct Formative Evaluation Of Instruction, (9) Revise Instruction, (10) Design And Conduct Summative Evaluation. Desain uji coba produk dalam penelitian ini melalui tiga tahap yaitu (a) validasi ahli, (b) uji coba kelompok kecil, (c) uji coba kelompok besar. Hasil uji coba selanjutnya diuji dengan Uji $t$ yaitu untuk mengetahui peningkatan kemampuan kemampuan sosial dan emosionalanak usia dini dari hasil belajar antara memakai media dengan tidak memakai media. Hasil penelitian menunjukkan bahwa video sex education dapat menstimulasi kemampuan sosial dan emosional anak. Dari hasil analisis data memperoleh memperoleh nilai signifikasi $0,000<0,005$ maka $\mathrm{H}_{0}$ ditolak. Dengan demikian dapat dikatakan adanya perbedaan pada rata-rata perlakuan sebelum dan sesudah dan rata-rata skor perlakuan sebelum dan sesudah perlakuan pada proses pembelajaran sex education dengan menggunakan video yang telah dikembangkan.
\end{abstract}

Kata kunci: media video, sex education, kemampuan sosial dan emosional

\begin{abstract}
This research aims to develop video sex education to stimulate social emosional of childhood. The development model used in this study is a model (Gall et al., 2011), which consists of ten steps. (1) Asses Needs To Identity Goal, (2) Conduct Instructional Analysis, (3) Analyze Learners And Cnontext, (4) Write Performance Objectives, (5) Develop Assessment Instrument, (6) Develop Instructional Strategy, (7) Develop And Select Instructional Materials, (8) Design And Conduct Formative Evaluation Of Instruction, (9) Revise Instruction, (10) Design And Conduct summative Evaluation. Design trials of investigational products through three stages: (a) validation expert, (b) small group trial, (c) a large group trial. The trial results were further tested by t-test is to determine the increase in the ability of religious values and morals of the early childhood learning outcomes between consuming media by not wearing media. The results showed that audio-visual media can stimulate sex education religious values and morals. From the analysis of the data obtained derive significant value $0.000<0.005, \mathrm{HO}$ is rejected. Thus it can be said the difference in the average treatment before and after and the average score of the treatment before and after treatment in the learning process of sex education by using audio-visual media have been developed.
\end{abstract}


Keywords: video media, sex education, social and emotional abilities.

\section{PENDAHULUAN}

Dalam rangka mencerdaskan kehidupan bangsa, pemerintah selama ini telah berusaha mengembangkan banyak program pendidikan yang melibatkan berbagai lembaga yang ada di dalam masyarakat, program pendidikan tersebut guna menjangkau seluruh warga masyarakat dari yang atas sampai lapisan paling bawah. Pendidikan anak usia dini (PAUD) merupakan pendidikan yang amat mendasar, karena pada masa usia dini merupakan masa emas (golden age) dan peletak dasar bagi pertumbuhan dan perkembangan anak selanjutnya.

Pengertian anak usia dini secara umum adalah anak-anak yang berusia di bawah 6 tahun. Anak pada usia 4 sampai 6 tahun atau usia Taman Kanak-kanak (pada jalur pendidikan formal sesuai dengan Undang-undang RI Nomor 20 tahun 2003 pasal 28 tentang Pendidikan Anak Usia Dini), merupakan masa peka bagi anak, karena masa ini merupakan masa terjadinya pematangan fungsifungsi fisik dan psikis yang siap merespon stimulasi lingkungan dan menginternalisasikan ke dalam pribadinya. Masa ini merupakan masa awal perkembangan fisik, kognitif, bahasa, sosial, emosional, konsep diri, disiplin, kemandirian, seni, moral, dan nilai-nilai agama. Oleh karena itu dibutuhkan suatu kondisi dan stimulasi yang sesuai dengan kebutuhan anak agar pertumbuhan dan perkembangan tercapai secara optimal (Kemendiknas, 2013).

Menurut Aqib (2009:9-10), Taman Kanak-kanak (TK) sebagai salah satu bentuk satuan Pendidikan Anak Usia Dini (PAUD) yang bertujuan untuk membantu meletakkan dasar ke arah perkembangan sikap, pengetahuan, keterampilan dan daya cipta yang diperlukan oleh anak dalam menyesuaikan diri dengan lingkunganya serta untuk pertumbuhan dan perkembangan selanjutnya.

Perkembangan anak meliputi segala aspek kehidupan yang mereka jalani baik fisik maupun non fisik. Kesepakatan para ahli menyatakan bahwa yang dimaksud dengan perkembangan adalah suatu proses perubahan pada seseorang ke arah yang lebih maju dan lebih dewasa (Hurlock, 1978:28).

Secara umum, yang melatar belakangi penelitian ini adalah fakta empiris meningkatnya angka pelecehan seksual terhadap anak usia dini di Indonesia. Menurut data yang diperoleh Republika Online (ROL), pada tahun 2013 terdapat 925 kasus pelecehan seksual terhadap anak yang telah ditangani oleh Komisi Perlindungan Anak Indonesia (KPAl). Pelakunya dari berbagai lapisan, dimulai dari kerabat, guru, teman-temannya, maupun pekerja yang bekerja di rumahnya. Banyak kasus anak-anak yang menjadi korban pelecehan seksual yang dilakukan oleh orang dewasa bahkan terkadang kerabat dekatnya dan orangtua baru menyadari ketika kejadian tersebut sudah berlangsung berkali-kali. Hal itu biasanya dikarenakan ketidaktahuan anak bahwa telah terjadinya pelecehan sehingga tidak segera menceritakan hal tersebut pada orangtuanya. Ada juga anak laki-laki yang bersikap feminisme layaknya perempuan, atau anak-anak laki-laki yang melecehkan anak perempuan tanpa disadari. Sekali lagi hal ini dikarenakan ketidaktahuan anak tentang pengertian seks itu sendiri.

Berdasarkan observasi awal peneliti pada tanggal 04 September 2015 di TK Istiqlaliyah Manyar Gresik banyak guru memadang sex education itu seharusnya diberikan pada saat anaknya tumbuh remaja. Padahal sex education itu sangat penting diberikan sejak dini. Karena dengan mengenalkan sex education dengan menjelaskan konsep kebersihan untuk menjaga daerah genital sejak dini dapat mencegah terhindar dari kuman dan penyakit.

Sex education pada anak juga dapat mencegah agar anak tidak menjadi korban pelecehan seksual, dengan dibekali tentang pengetahuan tentang seks, anak akan mengerti perilaku mana yang tergolong pelecehan seksual. Dorongan rasa ingin tahu yang sangat tinggi pada anak usia dini ditujukan pada berbagai hal yang ada di sekitar mereka, termasuk berbagai hal yang berkaitan dengan seksualitas. Rasa ingin tahu anak yang memuncak tentang seksualitas biasanya diawali oleh kesadaran akan perbedaan bentuk fisik dan bentuk alat kelamin antara laki-laki dan perempuan. Hal ini kemudian semakin mendasari anak untuk melakukan eksplorasi lebih jauh terhadap dirinya sendiri dan teman sebaya. 
Salah satu sikap dasar yang harus dimiliki anak untuk menjadi manusia yang baik dan benar adalah memiliki sikap dan nilai moral yang baik dalam berprilaku sebagai umat Tuhan, anak, anggota keluarga dan anggota masyarakat. Usia di masa Pendidikan Anak Usia Dini adalah saat yang paling baik dan tepat untuk meletakkan dasar-dasar pendidikan nilai, moral, dan agama kepada anak. Walaupun peran orang tua sangatlah besar dalam membangun dasar sosial dan emosional bagi anakanaknya, peran pendidik Pendidikan Anak Usia dini juga tidaklah kecil dalam meletakkan dasar sosial dan emosional bagi seorang anak (Hidayat, 2007:38).

Pengembangan kemampuan sosiasl dan emosional erat kaitannya tentang budi pekerti seorang anak, sikap sopan santun, kemauan melaksanakan ajaran agama dalam kehidupan sehari-hari. Pembahasan filosofis tentang budi pekerti khususnya dari segi pendidikan moral sebagaimana dikemukakan oleh (Zuriah, 2014) akan terus berkembang dengan berbagai pendapat dan aspek budi pekerti. Dalam lingkup perkembangan kemampuan sosial dan emosional anak diharapkan dapat membedakan prilaku baik dan buruk. Pendidikan seks yang keliru yang diperoleh anak, serta anak-anak yang tidak memperoleh bimbingan dan arahan yang tepat dapat mengembangkan persepsi yang keliru tentang alat kelamin, proses reproduksi, dan seksualitas. Konsep pendidikan seks sebaiknya diberikan sejak dini.

Beberapa cara yang dilakukan orang tua untuk mengembangkan sikap nilai moral-agama pada anak adalah sebagai berikut; memberi contoh. Anak usia dini mempunyai sifat suka meniru, karena orang tua lingkungan pertama yang ditemui anak, maka ia cenderung meniru apa yang diperbuat oleh orang tuanya. Di sinilah peran orang tua untuk memberikan contoh yang baik bagi anak. Pengembangan moral agama pada program Pendidikan Anak Usia Dini sangat penting keberadaannya, jika hal itu telah tertanam dan terpatri dengan baik dalam setiap insane sejak dini, hal tersebut merupakan awal yang baik bagi pendidikan anak bangsa untuk menjalani pendidikan selanjutnya (Yani, 2011: 43).

Pengembangan aspek kemampuan sosial dan emosional anak usia dini dilakukan dengan kegiatan pembiasaan rutin dan keteladanan yang dilakukan oleh anak sehari-hari membuat seorang pendidik harus merancang kegiatan pembelajaran yang lebih terprogram apalagi menyangkut media dalam pembelajarannya. Ini sangat berpengaruh karena pembelajaran anak usia dini masih dalam kondisi bermain yang perencanaannya meliputi hal-hal yang menarik dan menyenangkan bagi anak. Media akan sangat menunjang perkembangan aspek perkembangan pada anak.

Media pembelajaran sebagai medium dalam penyampaian materi pembelajaran sangat berpengaruh terhadap keberhasilan kegiatan pembelajaran sehingga akan mudah dipahami oleh anak didik. Media merupakan salah satu komunikasi, yaitu membawa pesan dari komunikator menuju komunikan, (Daryanto, 2010:4). Dengan penyediaan media pembelajaran yang menarik, menyenangkan, dan berorientasi terhadap lingkungan sekitar, diharapkan anak akan dapat mengenal pentingnya sex education. Teknologi mampu menyediakan beragam media yang kaya dan fleksibel untuk mewakili apa pun yang siswa sudah ketahui dan apa yang sedang mereka pelajari (Priyanto, 2012:45).

Media pembelajaran audio visual sangat cocok sebagai media pembelajaran yang dikembangkan dan digunakan secara baik dan diharapkan akan bermanfaat bagi para pendidik. Video pembelajaran dipilih peneliti untuk mengembangkan sex education di TK Istiqlaliyah Manyar Gresik dengan pertimbangan yang matang. Media pembelajaran audio visual adalah media yang bisa dilihat oleh mata seperti gambar dan didengar oleh telinga. Secara umum manfaat yang diperoleh adalah proses pembelajaran lebih menarik, lebih interaktif, kualitas belajar siswa dapat ditingkatkan dan proses belajar mengajar dapat dilakukan di mana dan kapan saja, serta sikap belajar siswa dapat ditingkatkan, (Daryanto, 2010:52).

Setelah melihat kedudukan media dalam pengajaran di mana media ada dalam komponen metode mengajar sebagai salah satu upaya untuk mempertinggi proses interaksi guru dan anak serta lingkungan belajarnya. Oleh sebab itu fungsi utama dari media pembelajaran adalah sebagai alat bantu 
mengajar, yakni menunjang penggunaan metode mengajar yang digunakan guru. Pengembangan kemampuan sosial dan emosional pada anak usia dini sangat memerlukan penunjang media karena melalui kegiatan pembiasaan saja membuat pemahaman konsep sosial dan emosional perlu dipertegas dengan contoh-contoh prilaku kongkret dalam penayangan video sex education untuk anak usia dini.

Terkait dengan fasilitas yang ada di lembaga serta tuntutan profesionalisme guru yang harus mampu mengelola informasi dan lingkungan untuk memfasilitasi kegiatan anak dalam mengenalkan sex education maka peneliti ingin mengenalkan video dalam mengenalkan sex education, peneliti memilih media berupa video pembelajaran sebab media pembelajaran yang dikembangkan dan digunakan secara baik diharapkan akan bermanfaat bagi pendidik anak usia dini.

Dalam penelitian ini peneliti menggunakan video dalam bentuk VCD (video compact disc), di dalam VCD tersebut diantaranya menjelaskan tentang konsep tubuh yang harus dijaga dan dilindungi, konsep baju ketika keluar dari rumah, serta konsep ketika anak buang air kecil atau buang air besar.

Berdasarkan paparan di atas, muncul pertanyaan penelitian, apakah video sex education yang dikembangkan dapat menstimulasi kemampuan sosial dan emosional anak kelompok B. Oleh karena itu penelitian ini diselenggarakan bertujuan untuk mengetahui keefektifan video sex education dalam menstimulasi kemampuan sosial dan emosional anak kelompok B.

\section{METODE PENELITIAN}

Penelitian tentang pengembangan video sex education untuk menstimulasi kemampuan sosial dan emosional anak kelompok B TK Istiqlaliyah Manhyar Gresik ini menggunakan model pengembangan (Gall et al., 2011) mengadaptasi pendekatan system yang dikembangkan oleh Dick and Carey.

Prosedur pengembangan video sex education ini untuk menstimulasi perkembangan kemampuan sosial dan emosional pada anak umur 5-6 tahun. Dalam pengembangan ini menghasilkan produk media pembelajaran berupa video sex education untuk menstimulasi kemampuan sosial dan emosional yaitu dengan meggunakan 10 tahapan sebagai berikut: (1) Assessneeds to Identity Instructional Goals (Menganalisis Kebutuhan untuk Mengidentifikasi Tujuan). (2) Conduct Instructional Analyze (Melakukan Analisis Instruksional). (3) Analyze Learners and Contexts (Mengidentifikasi perilaku dan karakteristik awal anak). (4) Write Performance Objectives (Merumuskan Tujuan Instruksional Khusus). (5) Develop Assessment Instrument (Pengembangan Tes Acuan Patokan). (6) Develop Instructional Strategy, (Mengembangkan Strategi Instruksional Khusus). (7) Develop and Select Instructional Materials (Mengembangkan bahan instruksional). (8) Design and Conduct Formative Evaluation of Instruction, (Mendesain dan menyelenggarakan evaluasi formatif). (9) Revise Instruction. (Merevisi Instruksional). (10) Design And Conduct Summative Evaluation.

Pada tahap penelitian ini dilakukan desain uji kelayakan draf 1 berupa video sex education dalam bentuk VCD yang di dalamnya menjelaskan konsep sex education diantaranya adalah konsep tubuh yang harus dijaga, konsep baju ketika keluar dari rumah, serta konsep BAB dan BAK. Uji coba ini meliputi uji coba ahli media, uji coba ahli materi dan uji coba ahli pembelajaran. Dari hasil penelitian ahli akan dianalisis dan hasilnya akan menentukan revisi atau tidaknya desain produk yang dihasilkan. Bila perlu direvisi, maka hasil validasi dijadikan bahan revisi untuk menghasilkan draf II, sampai akhirnya bahwa produk tersebut layak diuji cobakan.

Pada tahap uji kelompok kecil pengujian dilakukan pada beberapa anak untuk mendapatkan respon anak dari materi yang diajarkan, hasilnya digunakan sebagai revisi produk yang akan menghasilkan draf III. Tahap ini dilakukan oleh peneliti kepada 15 anak TK Kelompok B dan guru kelasnya. Tahap ini bertujuan untuk mengetahui kemenarikan dan kesesuaian media pembelajaran yang dikembangkan.

Pada tahap uji lapangan pengujian dilakukan dengan menerapkan video sex education untuk membedakan prilaku yang baik dan buruk sebagai media pembelajaran di Kelompok B. Hasil uji coba akan dijadikan bahan revisi sehingga produk siap dipakai. 


\section{HASIL DAN PEMBAHASAN}

Hasil analisis data dari pengembangan produk media pembelajaran berupa video tentang pengenalan sex education, menunjukkan kelayakan pada hasil uji coba ahli media, ahli materi, ahli pembelajaran, uji coba perorangan dan uji coba kelompok kecil.

Hasil angket yang telah divalidasi oleh ahli media menyatakan bahwa media video pembelajaran sex education yang telah dikembangkan menunjukkan bahwa dari seluruh variabel dan sub variabel dinyatakan layak, sehingga dapat dikatakan bahwa media tersebut layak digunakan dari sisi kualitas isi, dan kualitas instruksional. Validator menunjukkan bahwa video pembelajaran ini dapat digunakan dan ditindaklanjuti pada uji kelompok kecil.

Penilaian dari ahli materi dengan variabel komponen materi, pengorganisasian komponen materi, pemilihan media belajar, dan kegiatan pembelajaran sex education dari seluruh variabel dan sub variabel sesuai sehingga dapat dikatakan layak digunakan. Catatan yang diberikan bahwa pada RPPH (Rencana Pelaksanaan Pembelajaran Harian) pada kolom metode pembelajaran ada yang belum benar tetapi pada akhirnya sudah dibetulkan oleh peneliti. Pada penilaian pembelajaran kolom rubrik penilaian belum dijelaskan secara jelas sehingga peneliti perlu merevisi sedikit.

Selanjutnya adalah validasi yang disampaikan oleh ahli desain pembelajaran anak usia dini, dari variabel dan indikator adalah sesuai sehingga dapat dikatakan media tersebut layak digunakan dari sisi materi dan bahasa yang ditampilkan. Menurut catatan yang diberikan bahwa dari variabel bahasa seharusnya perlu perbaikan dari redaksi bahasa tentang orang yang tidak dikenal.

Untuk uji coba terbatas atau uji coba kelompok kecil dilakukan kepada 15 anak dari kelompok B3 dari enam pertanyaan bahwa sebagian besar $(94,4 \%)$ anggota kelompok kecil memberikan jawaban "ya" dan hanya sebagian kecil $(5,6 \%)$ memberikan jawaban "tidak" sehingga dapat dikatakan media video tersebut layak untuk digunakan.

Dari uji kelompok besar/ uji lapangan pada kelompok eksperimen dan kelompok kontrol diperoleh perhitungan dengan menggunakan uji $t$ untuk mengetahui peningkatan kemampuan anak usia dini dalam mengenal sex education. Ada 4 konsep yang diujicobakan pada kelompok eksperimen yang menggunakan video dan kelompok kontrol tanpa menggunakan media.

Pengenalan sex education dengan konsep mengenal nama dan umurnya memperoleh nilai signifikasi $0,000<0,005$ maka $\mathrm{H}_{0}$ ditolak. Dengan demikian dapat dikatakan adanya perbedaan pada rata-rata perlakuan sebelum dan sesudah dan rata-rata skor perlakuan sebelum dan sesudah perlakuan pada proses pembelajaran sex education dengan menggunakan video yang telah dikembangkan. Dengan kata lain bahwa dengan menggunakan video sex education dapat menstimulasi kemampuan sosial dan emosionalpada anak usia dini.

Pengenalan sex education dengan konsep tubuh yang harus dilindungi memperoleh nilai signifikasi 0,000 < 0,005 maka $\mathrm{H}_{0}$ ditolak. Dengan demikian dapat dikatakan adanya perbedaan pada rata-rata perlakuan sebelum dan sesudah dan rata-rata skor perlakuan sebelum dan sesudah perlakuan pada proses pembelajaran sex education dengan menggunakan video yang telah dikembangkan. Dengan kata lain bahwa dengan menggunakan video sex education dapat menstimulasi kemampuan sosial dan emosionalpada anak usia dini.

Pengenalan sex education dengan konsep baju ketika keluar rumah memperoleh nilai signifikasi $0,000<0,005$ maka $\mathrm{H}_{0}$ ditolak. Dengan demikian dapat dikatakan adanya perbedaan pada rata-rata perlakuan sebelum dan sesudah dan rata-rata skor perlakuan sebelum dan sesudah perlakuan pada proses pembelajaran sex education dengan menggunakan video yang telah dikembangkan. Dengan kata lain bahwa dengan menggunakan video sex education dapat menstimulasi kemampuan sosial dan emosionalpada anak usia dini.

Pengenalan sex education dengan konsep buang air kecil dan buang air besar memperoleh nilai signifikasi $0,000<0,005$ maka $\mathrm{H}_{0}$ ditolak. Dengan demikian dapat dikatakan adanya perbedaan pada rata-rata perlakuan sebelum dan sesudah dan rata-rata skor perlakuan sebelum dan sesudah perlakuan pada proses pembelajaran sex education dengan menggunakan video yang telah 
dikembangkan. Dengan kata lain bahwa dengan menggunakan video sex education dapat menstimulasi kemampuan sosial dan emosionalpada anak usia dini.

Dari hasil perhitungan di atas pada pengenalan empat konsep tersebut dapat disimpulkan bahwa dengan menggunakan video sex education yang yang telah dikembangkan dapat menstimulasi kemampuan sosial dan emosionalpada anak usia dini.

Dari hasil uji coba lapangan menunjukkan adanya keefektifitasnya dalam kegiatan pembelajaran dengan meningkatnya kemampuan anak dalam pembelajaran sex education yang dibuktikan melalui peningkatan hasil belajar pada kelompok eksperimen.

Pengembangan media pembelajaran berupa video untuk anak usia dini yang telah dikembangkan dalam penelitian ini memperhatikan teori yang dikemukakan oleh Seel \& Richey (1994:10) bahwa teknologi pembelajaran konseptual didefinisikan sebagai sebuah teori dan praktek dalam mendesain, pengembangan, pemanfaatan, pengelolaan, dan evaluasi proses, serta sumber belajar. Juga sesuai dengan teori yang dikemukakan oleh (Permana \& Nourmavita, 2017) bahwa media sebagai alat komunikasi guna lebih mengefektifkan proses pembelajaran. Fungsi media dalam rangka mencapai tujuan pendidikan. Dari teori tersebut menunjukkan pentingnya media bagi keberhasilan dalam kegiatan pembelajaran.

Media pembelajaran audio visual berupa video tentang pengenalan sex education yang telah dikembangkan dalam penelitian ini merupakan produk pengembangan yang bertujuan untuk menstimulasi kemampuan sosial dan emosionalanak usia dini pada kelompok B TK Istiqlaliyah Manyar Gresik. Hasil uji lapangan ditemukan bahwa penggunaan video berupa video yang dikembangkan terbukti efektif menstimulasi kemampuan sosial dan emosional pada anak kelompok B TK Istiqlaliyah Manyar Gresik.

Kelayakan untuk menstimulasi dalam penelitian ini sesuai dengan pendapat Munadi (2008:47) bahwa media tidak hanya memberikan pengalaman nyata tetapi juga membantu anak mengintegrasikan pengalaman-pengalaman anak selanjutnya. Dengan demikian diharapkan media pembelajaran akan dapat memperlancar proses belajar anak serta pemahaman terhadap materi pembelajaran. Disamping itu media pembelajaran dapat menarik perhatian serta mampu membangkitkan minat dan meningkatkan motivasi belajar anak. Motivasi merupakan seni yang mampu mendorong anak untuk melakukan kegiatan belajar sehingga tujuan belajar dapat tercapai.

Dengan demikian maka hasil penelitian ini terbukti telah mendukung teori Daryanto (2010:86) bahwa video merupakan suatu medium yang sangat efektif untuk membantu proses pembelajaran, baik untuk pembelajaran misal, individual, maupun kelompok.

Hasil penelitian ini juga membuktikan teori Arsyad (2002:48-49) bahwa ada beberapa keuntungan dalam penggunaan video sebagai media pembelajaran antara lain dapat melengkapi pengalaman dasar dari anak ketika membaca, berdiskusi, berpraktek, serta memperlihatkan alam sekitar yang tidak dapat dilihat secara langsung. Pernyataan ini sesuai karena dengan mengenalkan konsep tubuh yang harus dilindungi dapat menyajikan gambar yang jika dilihat langsung tidak mungkin tetapi jika ditampilkan dalam video dapat ditampilkan karena dengan menggunakan tokoh animasi. Dapat menggambarkan suatu proses secara tepat yang dapat disaksikan secara berulang jika diperlukan. Dengan video yang telah dikembangkan berupa video sex education dapat diputar berkalikali sehingga jika anak kurang faham bisa diputar kembali.

Pemilihan tema diri sendiri dan sub tema mengenal tubuhku yang disajikan dalam media audio visual berupa video ini sesuai dan relevan dengan kebutuhan program pembelajaran dan tuntutan zaman (Kementerian Pendidikan Nasional Republik Indonesia, 2009), dimana pengenalan sex education merupakan salah satu tema yang diajarkan pada pendidikan anak usia dini berupa video dengan memanfaatkan ITC.

Dengan pengembangan media pembelajaran berupa video dalam pengenalan sex education kita dapat memberikan pengalaman nyata pada anak usia dini, hal ini sesuai dengan penelitian yang dilakukan oleh British Audio Visual Association dalam (Zaman, 2005:46) menghasilkan temuan bahwa 
rata-rata jumlah informasi yang diperoleh seseorang melalui indra menunjukkan komposisi sebagai berikut :75\% melalui indra penglihatan (visual), 13\% melalui indra pendengaran (auditori) $6 \%$ melalui indra sentuhan/ perabaan, indra penciuman dan lidah.

Maka dapat disimpulkan bahwa media pembelajaran yang telah dikembangkan layak digunakan sebagai media pembelajaran untuk menstimulasi kemampuan sosial dan emosional anak usia dini.

\section{SIMPULAN}

Berdasarkan data dan pembahasan yang telah diperoleh maka proses pengembangan dan uji coba produk video berupa video untuk menstimulasi kemampuan sosial dan emosional anak usia dini dapat disimpulkan bahwa berdasar hasil penelitian menunjukkan implmentasi video sex education ini sangat menarik bagi anak dan dapat mendukung proses pembelajaran yang sedang berlangsung, sehingga perkembangan kemampuan sosial dan emosionalsesuai dengan peraturan Menteri Pendidikan Nasional nomor 58 dapat meningkat. Penggunaan video sex education dalam bentuk video terbukti efektif dapat menstimulasi kemampuan sosial dan emosional anak usia dini. Hal ini dapat dilihat dari uji kelompok besar/ uji lapangan dari keempat konsep yaitu mengenal nama dan umur, tubuh yang harus dilindungi, baju ketika keluar rumah dan buang air kecil dan buang air besar semuanya memperoleh nilai signifikasi 0,000 $<0,005$ maka $\mathrm{H}_{0}$ ditolak. Dengan demikian dapat dikatakan adanya perbedaan pada rata-rata perlakuan sebelum dan sesudah dan rata-rata skor perlakuan sebelum dan sesudah perlakuan pada proses pembelajaran sex education dengan menggunakan video yang telah dikembangkan. Dengan kata lain bahwa dengan menggunakan video sex education dapat menstimulasi kemampuan sosial dan emosionalpada anak usia dini.

Saran yang dapat disampaikan dalam pengembangan produk media pembelajaran ada tiga kategori yaitu video sex education dalam bentuk video pembelajaran yang telah dikembangkan dapat digunakan pendidik dalam membantu menyampaikan materi pembelajaran pada tema diri sendiri dengan sub tema mengenal tubuhku. Produk pengembangan video sex education dalam bentuk video pembelajaran yang telah dikembangkan merupakan media alternatif untuk menyampaikan pesan dan konsep. Diharapkan agar produk ini dapat disebarluaskan dan digunakan pendidik secara luas, khususnya bagi pendidik TK Istiqlaliyah Manyar Gresik. Dalam penggunaan produk ini juga harus disertai dengan fasilitas teknologi yang menadai seperti komputer/laptop, tape recorder, sound system, LCD, proyektor, TV, VCD untuk memfasilitasi produk ini sehingga dapat digunakan secara maksimal. Bagi yang ingin mengembangkan produk lebih lanjut untuk materi yang lain disarankan agar dapat menyesuaikan dengan karakteristik peserta didik sebagai pengguna akhir dari produk. Produk media pembelajaran dalam bentuk video adalah bentuk multimedia yang menghasilkan media pembelajaran pengenalan sex education untuk menstimulasi kemampuan sosial dan emosionalpada anak usia dini, jika ingin mengembangkan disarankan untuk mengembangkan materi pembelajaran yang lain. Dalam menggunakan produk ini hendaknya terus dilakukan evaluasi terhadap materi baik secara teori, gambar, dan suaranya karena perkembangan ilmu pengetahuan selalu ada yang baru, tapi tidak boleh menyimpang dan tetap mengecu pada standar kurikulum yang berlaku.

\section{DAFTAR RUJUKAN}

Aqib. 2009. Belajar dan Pembelajaran di Taman Kanak-Kanak. Bandung: Yrama Widya Arsyad Azhar. 2011. Media Pembelajaran. Jakarta. Rajawali Pers.

Daryanto. 2009. Panduan Proses Pembelajaran. Teori dan Praktek Dalam Pengembangan Profesionalisme Guru. Jakarta: Av:Publisher

Departemen Pendidikan Nasional. 2003. Petunjuk Pelaksanaan Kegiatan Belajar Mengajar, Penilaian Pembuatan dan Penggunaan Sarana (Alat Peraga) di Taman Kanak-Kanak. Jakarta: Depdiknas 


\section{Norma Diana Fitri}

Gall, M., Gall, J., \& Borg, W. (2011). Educational Research. Educational Research (Vol. 1).

Kemendiknas. (2013). Undang-Undang Republik Indonesia Nomor 20 Tahun 2003 Tentang Sistem Pendidikan Nasional. Undang-Undang Republik Indonesia.

https://doi.org/10.1017/CB09781107415324.004

Kementerian Pendidikan Nasional Republik Indonesia. (2009). Permendiknas 70 Tahun 2009 tentang Pendidikan Inklusif. Permendiknas 70 Tahun 2009 Tentang Pendidikan Inklusif.

Permana, E. P., \& Nourmavita, D. (2017). PENGEMBANGAN MULTIMEDIA INTERAKTIF PADA MATA PELAJARAN IPA MATERI MENDESKRIPSIKAN DAUR HIDUP HEWAN DI LINGKUNGAN SEKITAR SISWA KELAS IV SEKOLAH DASAR. Jurnal PGSD, 10(2), 79-85.

Zuriah, N. (2014). Analisis Teoritik tentang Etnopedagogi Pendidikan Kewarganegaraan sebagai Wahana Pendidikan Budaya dan Karakter Bangsa di Perguruan Tinggi. SOSIOHUMANIKA: Jurnal Pendidikan Sains Sosial Dan Kemanusiaan, 7(November), 175-188.

Zaman, Badru dkk. (2005). Media dan Sumber Belajar TK. Jakarta: Universitas Terbuka 